\title{
THE DEBRIS-LADEN ICE AT THE BOTTOM OF THE GREENLAND ICE SHEET
}

\author{
By. Sisax Herron. formerly Hoar, and Chester (i. Langway, Jr \\ Ice (iore Laboratory. Department of Geological Sciences. State Lniversity of New York at \\ Buffalo, Amherst. New York 14226 , U.S.A.)
}

\begin{abstract}
Anstract. The Camp Century. Greenland, ice core was recovered from a bore hole which extended $1375 \mathrm{~m}$ from the surface of the Greenland ice sheet to the ice/sub-ice interface. The bottom $15.7 \mathrm{~m} \mathrm{of}$ the core contain over 300 alternating bands of clear and debris-laden ice. The size of the included debris ranges from particles less than $2: 2 \mathrm{~m}$ in diameter $t o$ particle aggregates which are a maximum of $3 \mathrm{~cm}$ in diameter: the average debris concentration is $0.24^{\circ}$ " by weight. The debris size, concentration, and composition indicate that the debris originates from the till-like material directly below the debris-laden ice. The total gas concentration averages $51 \mathrm{ml} / \mathrm{kg}$ ice compared to the average of $101 \mathrm{ml} / \mathrm{kg}$ ice for the top $13 t^{\circ} \mathrm{m}$. The gas composition of debris-bearing ice has apparently been modified by the oxidation of methane as reflected by traces of methane, high $\left(\mathrm{C}_{2}\right.$ levels, and low $\left(\mathrm{O}_{2}\right.$ levels with respect to atmospheric air. Argon, which is not affected by the oxidation. shows an enrichment in samples with lower gas concentrations. Both the low gas concentration in the debris-laden zone and the argen enrichment may be explained by the downward diffusion of gases from bubbly glacier ice into an originally bubble-free zone of refrozen debrisladen ice. Ice texture and ice-fabric analyses reveal extremely fine-grained ice and highly preferred crystal orientation in the lowermost $10 \mathrm{~m}$ of the core, indicating a \%one of high deformation.
\end{abstract}

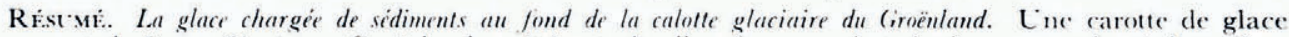
provenant de Camp Cientury. Grönland. a été extraite d'un forage qui atteignit $1375 \mathrm{~m}$ depuis la surface de la calotte groënlandaise jusqu à l’interface glace lit. les 15.7 mètes du bas de la carotte contiennent plus de zoo bandes alternées de glace claire et chargée de matiere. I a dimension des matériaux inclus va de particules de moins de $2 \mathrm{~km}$ en diamètre jusquà des agrégats qui ont jusqu à 3 cm de diamètre: la concentration movenne en sédiments est de $0,24^{\circ}$. en poids. La dimension. la concentration et la composition des sédiments indiquent qưils proviennent de dépôts de type morainique existant directement en-dessous de la glace chargée. I a concentration totale en gaz est en moyenne de $51 \mathrm{ml} \mathrm{kg} \mathrm{de} \mathrm{glace.} \mathrm{teneur} \mathrm{à} \mathrm{comparer}$ avec la moyenne de $101 \mathrm{ml} \mathrm{kg}$ pour la glace du sommet à $134^{\circ} \mathrm{m}$. I.a composition en gaz des sédiments chargeant la glace a été apparemment modifiéc par l'oxvdation du méthane comme il ressort des traces de méthane, de haute teneur en $\left(:()_{2}\right.$ et de faible concentration en $\mathrm{O}_{2}$ par rapport à la composition de l'air atmospherique. l.argon que l'oxydation n'affecte pas enrichit les échantillons qui ont la plus faible teneur en gaz. La faible teneur en gaz dans la zone chargè de materiaux et son enrichissement en argon peuvent etre expliqués par la diffusion vers le bas des gaz issus de la glace bulleuse du glacier vers la zone originellement dépourvue de bulles de la glace regelée chargée de sédiments. Les analyses de texture de la glace et d'orientation des axes optiques résèlent une glace à grains très fins et des orientations cristallines préférentielles très marquées dans les 10 derniers mètres de la carotte, prouvant que cette zone est le siège de nombreusess contraintes qui peurent étre dues aux irrégularités du lit.

\%usammenfassung. Das schuttbeladene läs am (irunde des grönländischen Ë̈sschildes. Der Eiskern von (amp (entury in Grönland wurde aus cinem Bohrloch cingebracht, das von der Oberfläche des grönländischen Inlandeises bis zur Grenzfläche zwischen Eis und Lntergrund in $1375 \mathrm{~m}$ Tiefe reichte. Die letzten $1.5,7 \mathrm{~m}$ des Kerns enthalten über 300 Bänder, die wechselweise aus klarem und schuttbeladenem Eis bestehen. Die (Frösse des cingeschlossenen Schuttes reicht von Partikeln mit Durchmessern kleiner als 2 um bis zu Partikelansammlungen. deren Durchmesser bis maximal $3 \mathrm{~cm}$ beträgt: Dic mittlere Schuttkonzentration liegt bei $0.24^{\prime \prime}$. des (iewichtes. (Frösse. Konzentration und Zusammensetzung des Schuttes lassen erkennen, dass dieser aus dem geschiebeähnlichen Material unmittelbar unter dem schuttbeladenen Eis stammt. Die gesamte Konzentration an (iasen beträgt im Mittel $51 \mathrm{ml}$ pro kg Eis, verglichen mit dem mittleren Gasgehalt von $101 \mathrm{ml}$ pro $\mathrm{kg}$ Eis für dic obersten $1340 \mathrm{~m}$. Die (jaszusammensetzung im schuttdurchsetzten Eis wurde offensichtlich durch die Oxydation von Methan verändert, was sich durch Spuren von Methan, hohen $\mathrm{C}:()_{2}-$ und niedrigen $\mathrm{O}_{2}$-( Gehalt, verglichen mit atmosphärischer Luft äussert. Argon, das durch die Oxydation nicht becinflusst wird, zeigt eine Anreicherung in Proben mit geringem Gasgehalt. Sowohl die niedrige (jaskonzentration in der schuttbeladenen Zone wie die Argonanreicherung lassen sich durch die Gasdiffusion aus blasenreichem Gletschereis abwärts in eine ursprünglich blasenfreic Zone wiedergefrorenen, schuttbeladenen Eises crklären. Analysen von Eistextur und -gefüge zeigen extrem feinkörniges Eis und hoch anisotrope Kristallorientierung in den untersten $10 \mathrm{~m}$ des Kerns; dies deutet auf eine Zone hoher Druckkonzentration, möglicherweise infolge von Lnregelmässigkeiten des Felsbettes.

\section{INTRODUCTION}

A continuous I $375 \mathrm{~m}$ ice core was recovered in 1966 from Camp Cientury, Greenland (lat. $77^{\circ} \mathrm{Io}^{\prime} \mathrm{N}$., long. $6 \mathrm{I}^{\circ}$ o8 $8^{\prime} \mathrm{W}$., elevation $\mathrm{r} 885 \mathrm{~m}$ ). The basal zone of this ice core contains numerous silt bands and small pebbles underlain by several meters of a till-like sub-ice material. This basal zone represents the first observed contact with debris-laden ice from the 
interior of an ice sheet and as such provides an excellent opportunity to observe the effects of basal processes on glacier ice. Several mechanisms have been proposed for the incorporation of basal debris. Among these are the transportation of material along shear planes (Goldthwait, I951, I960; Bishop, 1957), regelation (Kamb and LaChapelle, I964; Boulton, [ $\left.\left.{ }^{\mathrm{C}} \mathrm{I} 975\right]\right)$, dispersion of solid material due to the interactions between particles embedded in the ice and particles on the bed (Boulton, I967, I972, [ ${ }^{\mathrm{C}}{ }_{1975}$ ]; Weertman, 1968; Holdsworth, 1974), and surficial deposition on the ice sheet. However, a more commonly accepted concept is the freeze-on model, which postulates that the inclusion of debris in basal ice is due to a process of melting and subsequent refreezing of water at the base of an ice sheet (Weertman, I961, I964, I966, 1972). A detailed investigation of the structure and composition of the Camp Century basal debris-laden ice was conducted in order to determine which of these mechanisms may have been responsible for the incorporation of debris. The investigation was divided into several component studies: (1) the stratigraphy of the basal ice, (2) the size, concentration, and composition of the embedded debris, (3) the ice textures and fabrics, and (4) the volume and composition of gas inclusions. Evidence revealed through a laboratory investigation that any of these conditions ever existed in the basal ice, would contribute greatly to the development of flow laws for ice and the interpretation of its dynamic behavior. This in turn would provide greater accuracy in the dating of an ice-core sample from any given depth and would thus enhance the value of ice cores as paleoenvironmental indicators (Dansgaard and Johnsen, I969).

\section{Glaciological setting}

Camp Century is located in north-west Greenland at approximately $200 \mathrm{~km}$ from the west coast and $500 \mathrm{~km}$ from the present central ice divide. It is in the net accumulation zone of the ice sheet in an area where there is some summer melt (Benson, 1959; Mock, 1965). The length of the original Camp Century core was I $375 \mathrm{~m}$; the visible silt bands and pebbles were observed only in the bottom $16 \mathrm{~m}(<\mathrm{r} \%)$ of the core. The temperature at the base of the ice sheet is $-13^{\circ} \mathrm{C}$ (Hansen and Langway, i 966). Figure $\mathrm{I}$ shows the position of the Camp Century core and the zone of debris-laden ice with respect to an ideal ice sheet.

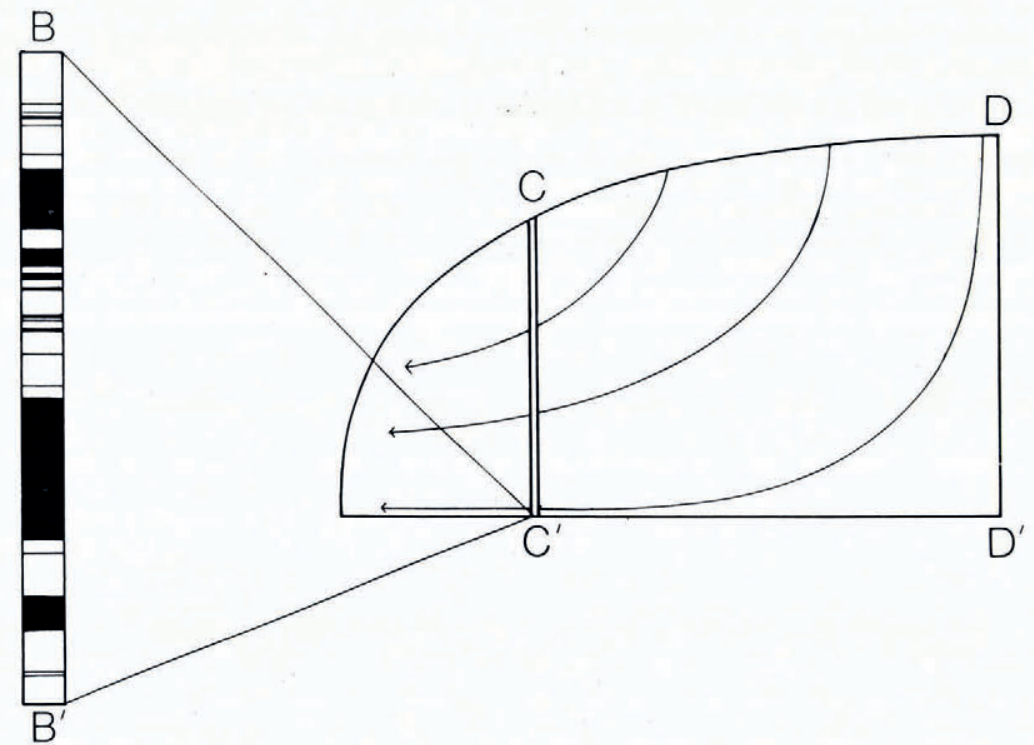

Fig. I. Glaciological setting of the Camp Century core. D-D' represents the ice-sheet divide; C-C' represents the Camp Century core; $B-B^{\prime}$ represents the debris-laden zone. 


\section{Estimated age of Camp Century ice core}

The origin of the debris at the base of an ice sheet and the mechanism by which it was emplaced are critical elements in estimating ice-core age. The Camp Century core spans an estimated time period of about 125000 years (Dansgaard and others, I969). This age estimation is based on the model of Dansgaard and Johnsen (r969), which assumes that the ice sheet is frozen to its bed and that melt water has never existed at the base of the ice sheet. If this assumption is correct, then the freeze-on mechanism proposed by Weertman (I96I) does not apply to the Camp Century core. However, if a layer of water did exist at any time during the glacial regime, then the age determination of Dansgaard and Johnsen (1969) may be greatly underestimated (Weertman, I976). The magnitude of the error near the bottom of the ice sheet would be of the order of $(h / a)(h / y)$, where $h$ is the thickness of the ice sheet, $a$ is the accumulation rate, and $y$ is the elevation of an ice particle above the bed. For Camp Century, using an accumulation-rate of $35 \mathrm{~cm} /$ year of ice (Crozaz and Langway, r966), the age of an ice particle $20 \mathrm{~m}$ above the bed could be underestimated by over 300 ooo years.

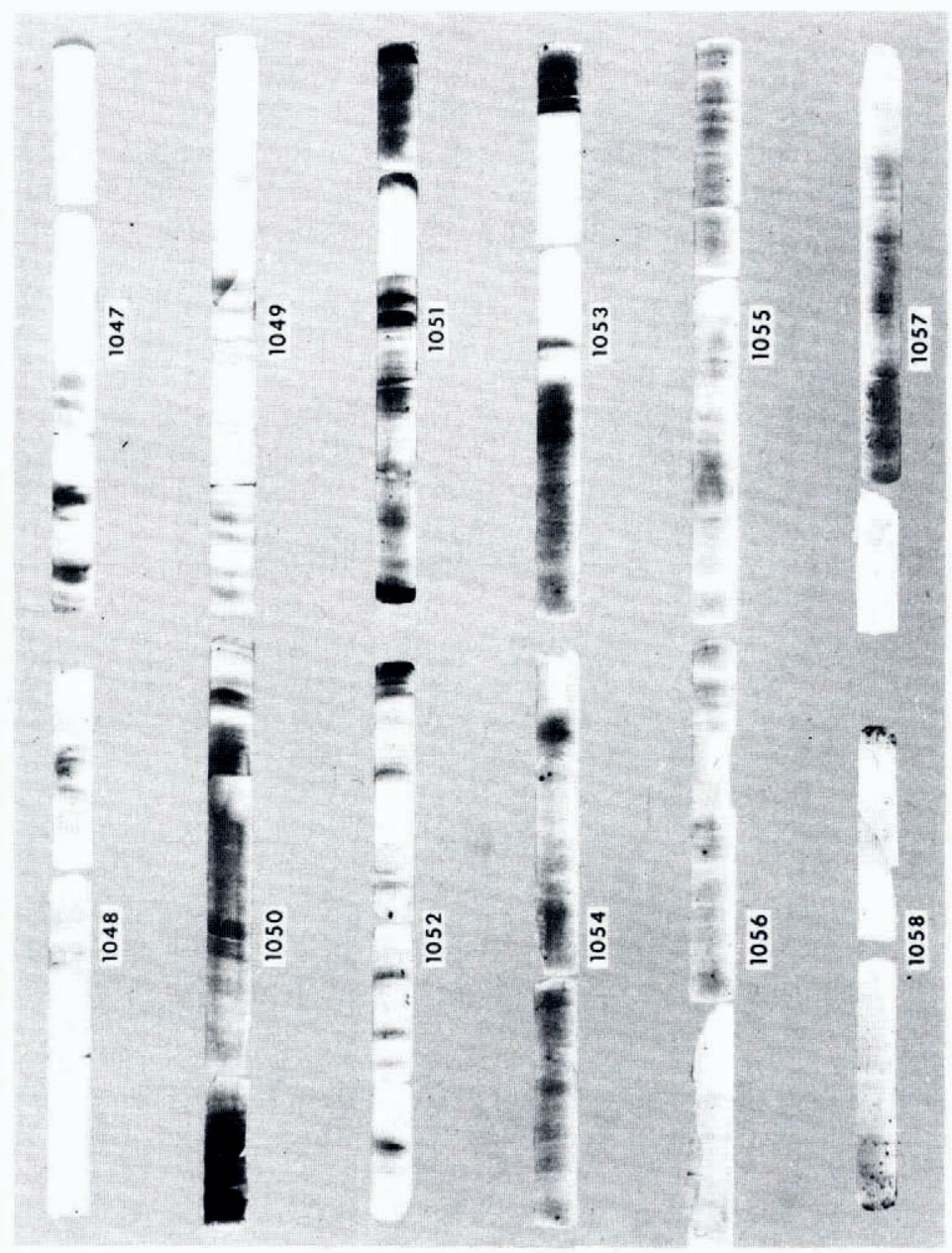

Fig. 2. Photograph of the bottom $17.1 \mathrm{~m}$ of the Camp Century ice core. Nimbers represent the core tube numbers. 


\section{Core samples}

A total of 16 core samples was selected for the component analyses. Three of the 16 samples were selected over a $3 \mathrm{~m}$ interval of clear glacier ice immediately overlying the debris-laden zone (i.e. above $16 \mathrm{~m}$ from the ice/sub-ice interface). The remaining 13 samples were selected from various layers in the debris-laden zone. The core was originally $10.2 \mathrm{~cm}$ in diameter; the samples used here consisted of $8 \mathrm{~cm}$ lengths of quarter core. Each sample was subdivided into pieces which were used for ice texture and fabric analyses, and for gas- and debris-concentration measurements. Gas-composition analyses were performed on four samples which were selected from intervals adjacent to those used for other studies reported here. (Of these samples, one was taken from clear ice above the debris-laden zone; three were taken from within the debris-laden zone.

\section{Rfsiluts AND Discussion}

\section{Ice stratigraphy}

A detailed inspection of the debris-laden zone was performed by transmitting light through the core in a cold laboratory where the temperature is maintained at $-10^{\circ} \mathrm{C}$. Megascopic features observed were air bubbles, debris particles and aggregates, debris bands, and clear ice layers. It was observed that the basal $15.7 \mathrm{~m}$ of the Camp Century ice core contain over 300 alternating bands of clear and debris-laden ice (Fig. 2). The debris bands and the clear ice layers range from less than a millimeter to over a meter in thickness and in the debris layers from light amber to dark brown in color. The embedded solid material ranges in size from particles so small that their presence is detected only by the color they impart to the ice to particle aggregates or blebs which are a maximum of $2-3 \mathrm{~cm}$ in diameter. The attitude of approximately $90 \%$ of the debris bands is within 5 of horizontal; the remaining bands are inclined at angles up to about $15^{\circ}$. Only $2^{\circ}$ of the inclination can be due to the inclination of the core hole (personal communication from B. L. Hansen). Nearly spherical air bubbles are visible throughout the entire zone, as are numerous disc-shaped bubbles similar to those described by Langway (1958[a]) and Gow (1971).

Various types of ice within the debris-laden zone were qualitatively classified according to color or light transmission. The categories consisted of clear, light, medium, and dark. The term "clear" is here used to refer to ice within the debris-laden zone which shows no discoloration due to debris and which has only a few visible particles. Using this light-transmission classification, the following distribution was observed in the $15.7 \mathrm{~m}$ debris-laden zone:

$$
\begin{aligned}
& 10^{\circ}{ }^{\circ} \text { clear. } \\
& 35^{\circ} \text { "light. } \\
& 53^{\circ} \text { " medium, } \\
& 2^{\circ} \text { " dark. }
\end{aligned}
$$

In the zones designated light or medium, about $20^{\circ}$ of of the debris-laden ice is interspersed with numerous lenses of clear ice. The transitions between bands are usually quite distinct; the order and thickness of the bands vary in a random manner.

On the basis of the banded structure and the distinct boundaries between the debris bands, it is possible to reject any type of dispersion or diffusion along temperature, pressure, or concentration gradients as the primary mechanism for the emplacement of the basal debris. By definition, such processes would be expected to produce a gradation of uniformly decreasing debris concentrations rather than the bands of debris present here. Plain observation of the basal stratigraphy does not provide clear evidence enabling differentiation between possible shear, freeze-on, and surficial deposition mechanisms. 


\section{Debris analysis}

The samples used in the debris analysis were the residue collected from core samples of the debris-laden ice which were melted during a previous study. Due to the low concentrations of debris in the ice and limited sample size, it was necessary to choose samples from the areas of highest particle concentration. 'Twenty-one samples were chosen on the basis of the amount of debris and the distribution throughout the basal zone. The average sample weighed about $0.35 \mathrm{~g}$ and it was separated by sieving and gravitational settling into three size categories:

1) clay size $(<2, \mathrm{~mm})$,

2) silt size $(2, \mu \mathrm{m} 62: \mu \mathrm{m})$,

3) sand size ( $>62 \mu \mathrm{m}$ with an observed upper limit of $2.0 \mathrm{~mm}$ ).

The sample recovery during the size-separation procedure averaged $98.7^{\circ} \%$. For each sample the relative percentage of each size fraction was calculated and normalized to $100^{\circ}{ }_{0}$. The data for each size fraction were fitted to a least-squares linear regression where the relative percentage $\left(y_{\mathrm{i}}\right)$ of material present in a given size category is a function of distance $\left(x_{\mathrm{i}}\right)$ from the bottom of the ice. The results obtained were:

clay-size fraction $y_{\mathbf{i}}=6.63+\mathrm{I} .64 x_{\mathbf{i}}$,

silt-size fraction $y_{\mathrm{i}}=30.12+1.07 x_{\mathrm{i}}$,

sand-size fraction $y_{\mathrm{i}}=63.25-2.71 x_{\mathrm{i}}$.

An analysis of variance was performed and it was found that the increase in clay-size material with increasing distance from the bottom and the corresponding decrease in sand-size material are statistically significant at a $99^{\circ}{ }^{\circ}$ oconfidence level. In the silt-size category, it was found that the amount of material does not vary significantly from the mean value of $y_{i}=39 \cdot 30$. The particle-size distribution and the significant regression lines are shown in Figure 3 .

The presence of a regular variation in grain-size with depth raises the question of whether the debris layers are a conformable sequence in which the uppermost material was the first to be emplaced at the farthest point up-stream and the lowest debris layer was more locally derived and recently emplaced. Boulton (1970) stated that this would be the case for the freezing hypothesis, whereas a shearing mechanism might produce a random pattern of debris layers. Souche\% $(1967)$ provided evidence supporting the idea that shearing results in a mixed sequence. If true, the grain-size gradation in the Ciamp Cientury ice might support a freezing mechanism. However, it is not possible to determine whether the decrease in particle size near the top of the debris-laden ice reflects a grain-size zonation in the sub-ice material, a geographic variation on the sub-ice material, or a selective mechanism of incorporation.

The grain-size of the embedded particles in the Camp Century basal ice ranges from less than $2 \mu \mathrm{m}$ to about $2.0 \mathrm{~mm}$ in diameter. A single pebble about $2 \mathrm{~cm}$ in length was observed. These particles are considerably larger than the atmospheric dust particles found in modern Greenland snow and Holocene and Wisconsin ice. The particulates in the upper I $355 \mathrm{~m}$ of the Camp Century ice core range from $0.04 \mu \mathrm{m}$ to $8 \mu \mathrm{m}$ (Kumai, 1977). This size difference supports the hypothesis that the basal debris originated as subglacial material rather than as atmospherically transported debris.

While the particle sizes are large compared to atmospheric dust, they are extremely small when compared to the cobbles and boulders often associated with glacial debris. These relatively small grain-sizes imply that some type of selective process is operating in the basal ice. For example, Souchez (1967) and Boulton ([ $\left.{ }^{c}{ }_{1975}\right]$ ) have both suggested that the incorporation of small particles and the exclusion of large ones may occur during the formation of regelation ice. A zone of individual particles suspended in the ice may result from the erosion of lithified bedrock, whereas ice containing particle aggregates may result from the incorporation of unconsolidated sediments (Boulton, 1970). In the Camp Cientury basal icc there are many particle aggregates and the material directly beneath the debris-laden ice 


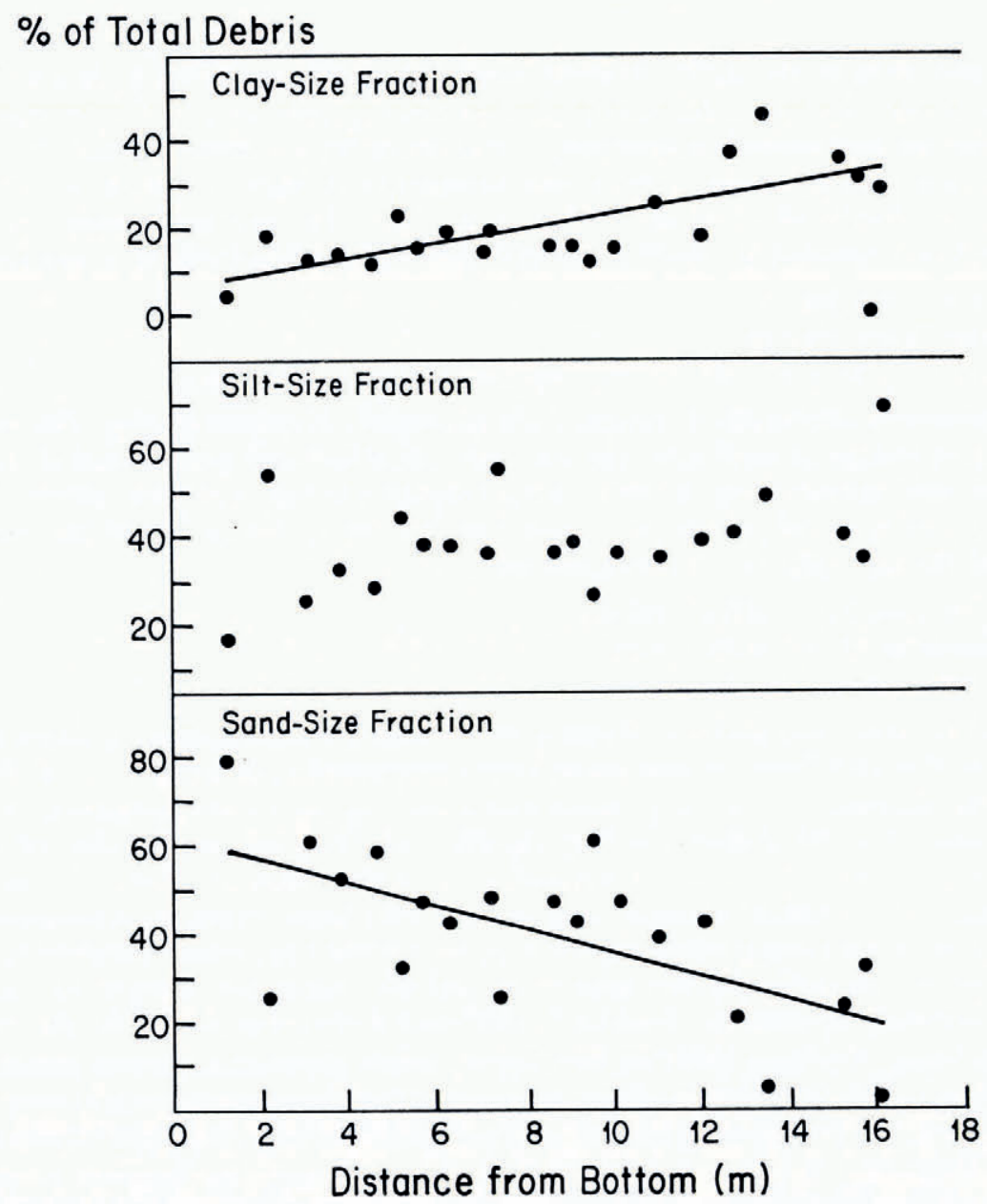

Fig. 3. Debris particle-size distribution.

horizon consists of an unconsolidated frozen till-like material (Hansen and Langway, 1966). This implies that a selective freezing mechanism is responsible for the incorporation of debris in the Camp Century core.

The concentration of debris in the ice was determined for the 16 core samples by filtering melt water through a $0.45 \mu \mathrm{m}$ "Millipore" filter. The values range from less than $0.001 \%$ by weight in ice above the debris-laden zone to a maximum of $0.9 \%$ in a sample taken from one of the dark-colored bands; the concentrations show no correlation with distance from the bottom. The debris-concentration values were compared with the ice-color designations of clear, light, medium, and dark that were assigned during the visual inspection of the core. On the basis of measured values, debris-concentration limits were established for the color classes. The average solid debris concentration in each color category was calculated. These averages were multiplied by the relative amount of ice present in each color class, thus yielding an average debris concentration of $0.24 \%$ by weight for the entire $15.7 \mathrm{~m}$ zone of debris-laden ice. The results are presented in Table I. The average debris concentration of $0.024 \%$ obtained for the clear ice bands within the debris-laden zone compares favorably with the 
silicate mineral concentration of $0.027 \%$ estimated by Kumai (1977) in his study on the Camp Century basal ice. This concentration is approximately four orders of magnitude greater than that in modern Greenland snow (Murozumi and others, 1969; Kumai, 1977) and Holocene ice (Kumai, I977), and three orders of magnitude greater than that in Wisconsin ice (Cragin and others, 1977). These high debris concentrations support a sub-ice origin for the debris, as also concluded by Kumai (1977).

TABle I. Debris concentration AND COlOR classification

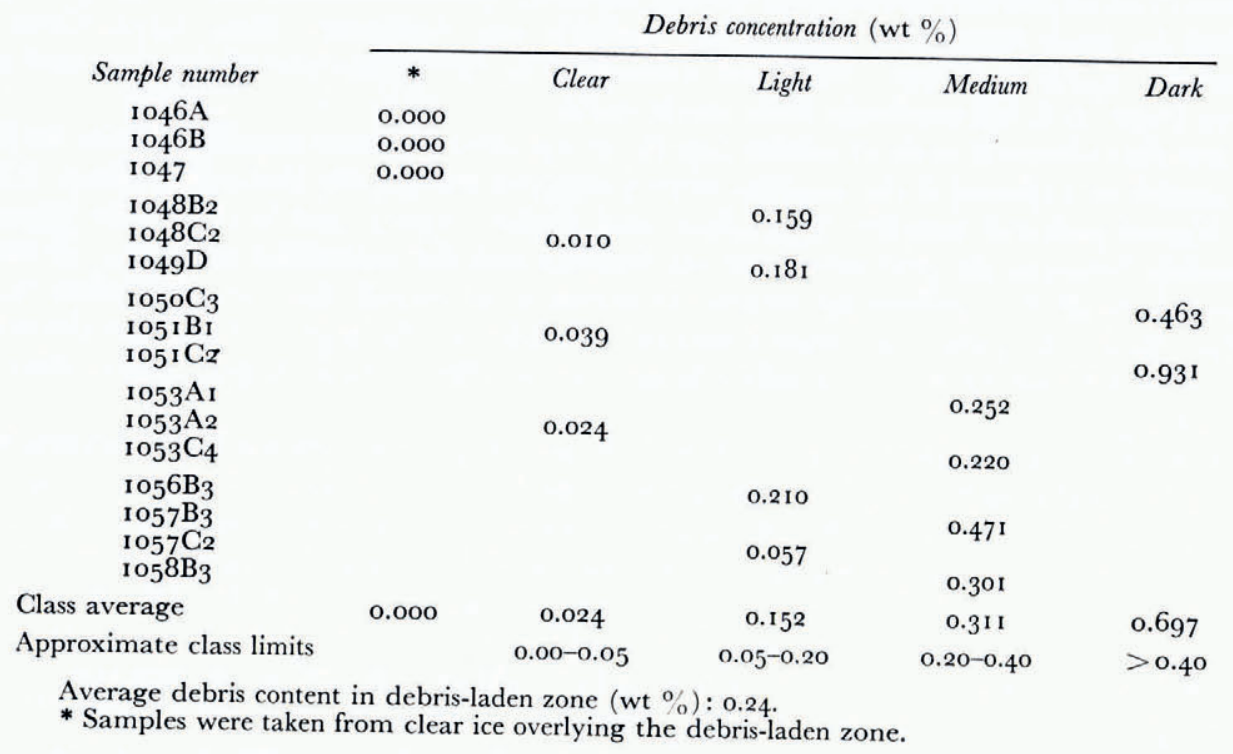

A microscopic examination of the debris revealed grain shapes and textures ranging from highly angular and pitted to well-rounded and smoothly ground. A scanning electron microscopic examination of quartz and feldspar particles from the Camp Century debris-laden zone by Whalley and Langway (in press), and Woo and others (1976), revealed similar textural observations. In both of these studies it was concluded that the rounded grains are probably the end products of glacial abrasion. It appears that the embedded particle shapes and textures reflect those of the underlying till-like material and reveal little about the mechanism by which they were emplanted.

An X-ray analysis was performed on six samples located at distances of $0.6 \mathrm{I}, 3.86,8.35$, I 5.42 , and I $5.71 \mathrm{~m}$ above the base of the ice sheet. The predominant mineral in each sample was found to be quartz; each sample also contains a plagioclase mineral identified as albite, some orthoclase, kaolinite, and hornblende. The similarity of all the X-ray patterns indicates that there is no significant mineralogical change over the entire $16 \mathrm{~m}$ debris-laden profile. This leads to the conclusion that either the sub-ice source material is of local origin or that it is uniform in nature on a larger or regional basis.

\section{Ice texture and ice fabric}

Vertical sections ( $4 \mathrm{~mm}$ thick) of the 16 ice-core samples were prepared and photographed in transmitted light using the method described by Langway (1958[a]). In thick section it was often difficult to differentiate between the gaseous and solid inclusions. 'Where air bubbles are easily recognized, they appear spherical to slightly elongated in the horizontal direction 
parallel to the base of the ice sheet; they exhibit a maximum length of about $0.7 \mathrm{~mm}$. The stretching of air bubbles has been attributed to shear deformation of ice but the degree to which this occurs and the statistical reliability of elongation as an indicator of shear strain has not been established (Kamb, 1973). In addition to the air bubbles, about $50 \%$ of the samples contain numerous disc-shaped inclusions, which are about $0.52 \mathrm{~mm}$ in diameter and are oriented parallel to the near-horizontal debris bands. In a few instances they form a swirling turbulent orientation. Although the inclusions appear to be similar to the vapor figures described by Nakaya ( $195^{6}$ ), vapor figures are air-free, whereas these disc-shaped inclusions were observed to produce air bubbles during melting. Similar features have been previously described in both Greenland (Langway, 1958|a|) and Antarctic (Gow, 1971; Gow and Williamson, 1975) ice cores. They are attributed to the relaxation of the ice core after recovery from its in situ confining stress environment.

It was also observed in thick section that there is neither a bubble stratification in the basal ice as would be expected if the bubbles were entrapped during the freezing of water (Corte, 1962; Kamb and La(hapelle. 1964; Bari and Hallett, 1974), nor is there any apparent relationship between the position of the air bubbles and the embedded particles. If the ice had been formed by a refreezing process, it would be expected that the particulate matter would act as sites for bubble nucleation and that bubbles would be present both on the surface of the particles and in lines extending from the particle surface (Corte, 1962; Bari and Hallett, 1974).

The thick sections were reduced to thin sections of approximately $0.3 \mathrm{~mm}$ thickness using a microtome and were photographed between crossed polarizing filters. In thin section it was observed that the ice crystals were very small and the crystal orientation was highly preferred. Consequently, the ice-crystal boundaries were not well defined and the average crystal area could not be measured in the manner described by Langway (1958[b]). In this study an estimate of average crystal diameter was obtained by determining the crystal-boundary density in at least six traverses of the section. The small crystal size and the highly preferred orientation also prevented measurement of individual crystal orientations using the Rigsby-type universal stage. A qualitative fabric analysis was therefore made on these sections by estimating the percentage area which went to extinction at one position.

The average ice-crystal diameters from a single traverse of a thin section ranged from 0.47 to $6.14 \mathrm{~mm}$; the average diameter per section ranges from 0.62 to $3.84 \mathrm{~mm}$. The average diameters for each sample are shown in Figure 4. A significant break in ice-crystal size diameter occurs at a distance of approximately $10 \mathrm{~m}$ from the bottom of the ice shect. In the lower $\mathrm{I} 0 \mathrm{~m}$ of the core, the ice is uniformly fine-grained with an average crystal diameter of only $0.79 \mathrm{~mm}$. Within the next $8 \mathrm{~m}$ there is a four-fold increase in crystal size. Similar changes in ice-crystal size were reported to occur at the boundaries between clear and debrisladen ice in basal ice from Terre Adélie, Antarctica (Lorius, 1967), and from the base of Meserve Glacier, Antarctica (Anderton, 1974). Lorius (1967) attributed the change to an increase in the stresses in zones where small crystals were observed. Such a change in stresses, possibly due to bedrock irregularities, could also explain the crystal-size change observed here.

A second element, which appears to be related to ice-crystal size, is the uniformity of the debris concentration. Samples with uniform debris concentrations, as determined by sample color, exhibit uniform textures regardless of whether the ice is light or dark, or whether the ice crystals are large or small. On the other hand, in areas where debris is concentrated in bands, the ice crystals in those bands are consistently smaller than in the adjacent ice. Similar results were reported in his Meserve Glacier report by Anderton (1974), who attributed the fine crystal size to differential shear acting across the debris-laden zone. Shumskiy (1958) and Swinzow (1964) also attributed small crystal sizes in debris-laden ice to the existence of differential shearing within those layers. 


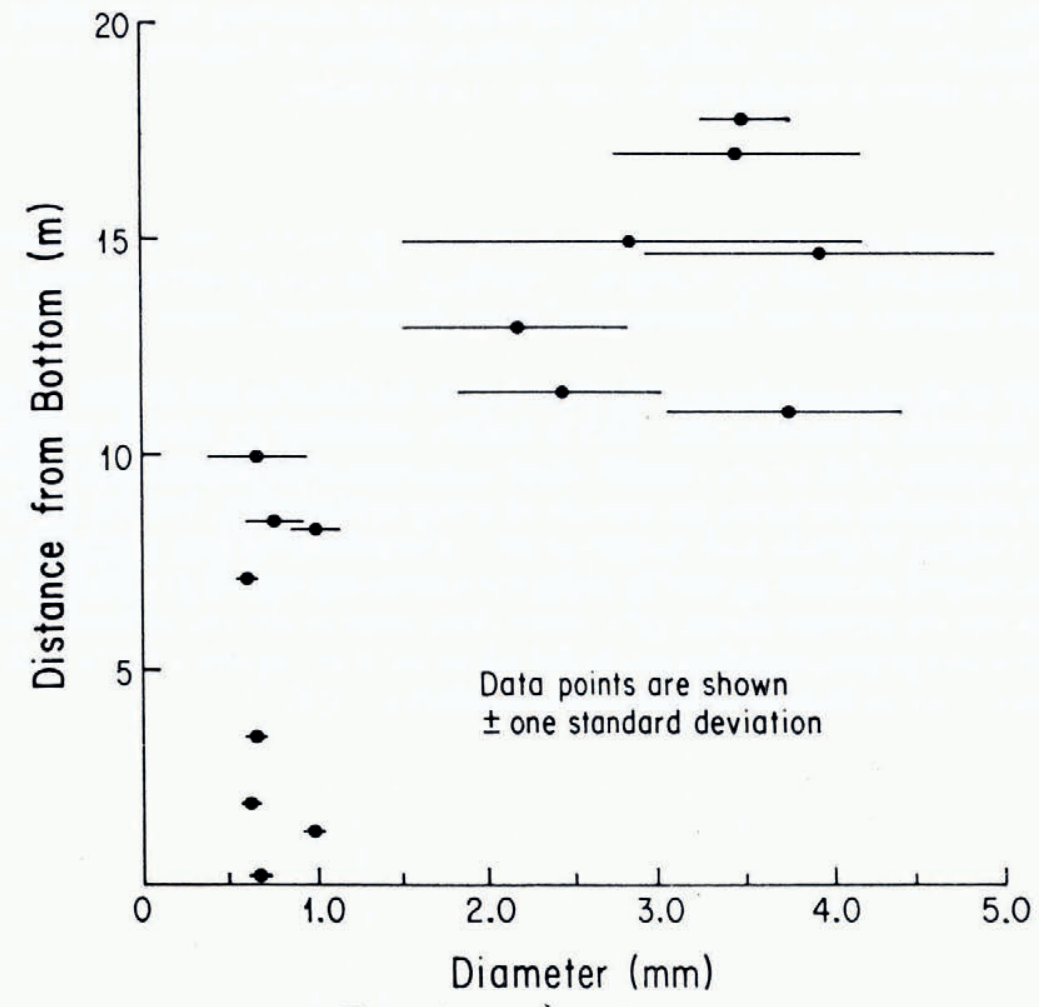

Fig. 4. Average ice-crvstal diameter.

The changes in crystal size are associated with changes in the ice fabrics. In the bottom Io $\mathrm{m}$, where the ice is fine-grained, the ice exhibits a highly preferred vertical orientation of optic axes. In all the samples from this zone it was estimated that $7595^{\circ}{ }_{0}$ of the ice crystals were extinct within a rotation of only a couple of degrees. Above this bottom to $\mathrm{m}$, the degree of preferred orientation diminishes rapidly to less than $50^{\circ}{ }_{1}$. The ice crystals in the debris bands do exhibit a preferred orientation but in some cases it is less extreme than in the adjacent ice. "

On the basis of the grain-size and fabrics in the Camp Century basal ice core, it is possible to make a conjecture about the existing stress-strain conditions (Shumskiy, I958; Steinemann, 1958; Rigsby, 1960; Kamb, r973). The zone of extremely fine-grained ice and the presence of highly preferred orientations in this lower basal zone indicate that it is a zone of relatively high shear deformation. The larger ice crystals and the weaker crystal orientations of the overlying basal ice imply that the shear stress and total strain are less than in the bottom ice. It is not possible to determine whether the relatively fine-grained nature of ice within the debris bands is due to the existence of relatively high shear deformation or whether the solid particles inhibit grain recrystallization.

It is interesting to note the difference between the size and orientation of ice crystals at the base of Camp Century where, in 1966 , the temperature was measured to be $-13^{\circ} \mathrm{C}$ (Hansen and Langway, 1966) and those from the base of Byrd Station, Antarctica, where the ice was at its pressure-melting temperature and melt water was present at the time of drilling in 1968 (Gow, 1970). The ice crystals from Byrd Station are about two orders of magnitude larger than those at Camp Century, and the fabric orientation is much weaker than observed 
in overlying ice (Gow, 1970, 1971). Gow attributed this situation to annealing of the ice occurring at temperatures near melting. The striking difference between the two reflects the vast difference in thermal conditions between the two locations.

\section{Gas analysis}

Density and total gas-content measurements were performed on the 16 core samples following the procedures used by Langway (1958[a]). Gas-composition analyses were performed on four samples at the University of Bern, Switzerland, under the direction of $\mathrm{H}$. Oeschger.

The density of all core samples was less than that of bubble-free ice, despite the presence of visible debris in many of the samples. This is readily explained by the low concentration of debris and the amount of air in the samples which counteracts the higher density of the debris. There was no correlation between the amount of debris and density, nor was there a correlation between amount of debris and volume of air. The volume of gas, corrected to s.t.p., in the 16 samples ranged between 34 and $64 \mathrm{ml} / \mathrm{kg}$ ice with an average of $5 \mathrm{I} \mathrm{ml} / \mathrm{kg}$ ice. These gas concentrations are on average about $50 \%$ lower than those in the rest of the Camp Century core where the average gas concentration is $108 \mathrm{ml} / \mathrm{kg}$ ice in the upper $1100 \mathrm{~m}$ and $10 \mathrm{I} \mathrm{ml} / \mathrm{kg}$ ice in the I IOO-I $300 \mathrm{~m}$ interval (Herron and Langway, I978).

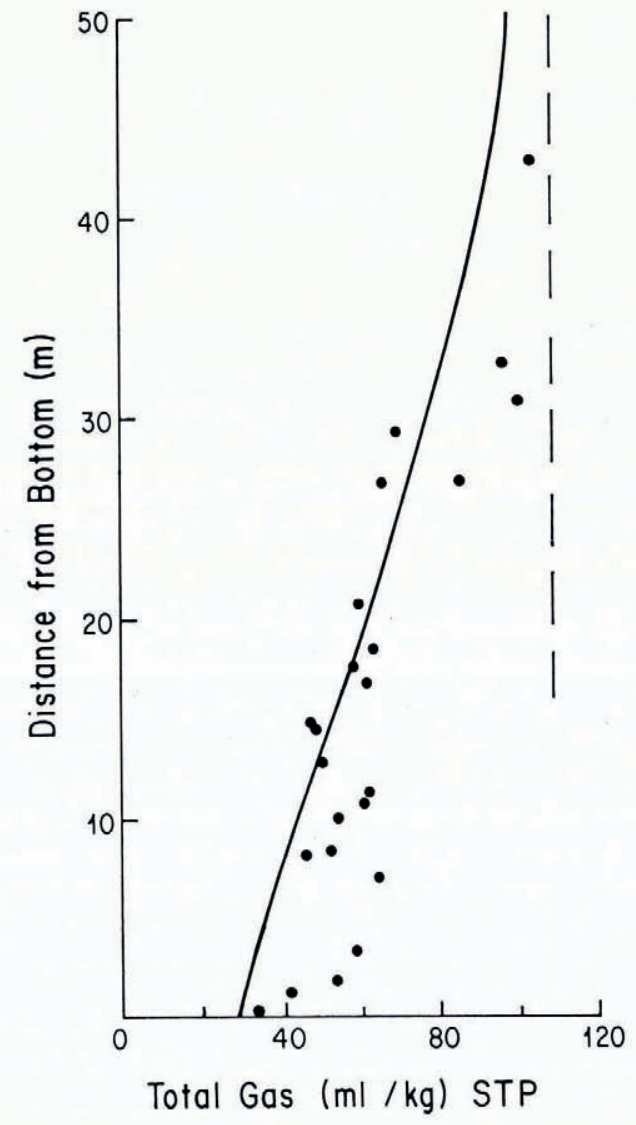

Fig. 5. Gas-concentration profile. 
One explanation for the low air content in the basal ice is that it may have originated at a higher elevation during a previous glaciation. Dansgaard and others (1969) have suggested that the oxygen-isotope data from the lowest $20 \mathrm{~m}$ of the ice core may represent periods of glaciation. Raynaud and Lorius (1973) have reported that a decrease in air content may reflect altitudinal increases during glaciation. Assuming their values of $7 \mathrm{~mm} \mathrm{Hg} / \mathrm{roo} \mathrm{m}$ for the pressure-elevation gradient and $0.9 \mathrm{deg} / \mathrm{roo} \mathrm{m}$ for the temperature-elevation gradient, it would require a $5000 \mathrm{~m}$ increase above the present-day Camp Century elevation to explain the low gas content in the Camp Century basal ice. Such an elevation increase is a factor of 4 greater than that proposed by Raynaud and Lorius (1973) for the Wisconsinan glaciation, and it is probably unrealistic.

The amount of air present in these samples is also incompatible with a simple freeze-on process during which gases would be expelled (Coachman and others, I 958; Bari and Hallett, I974). The average total gas content of $51 \mathrm{ml} / \mathrm{kg}$ ice is approximately half-way between the expected values of near zero for a simple freezing model and near ioo for the overlying glacier ice. The abnormal gas content may be explained by a model in which bubble-free debrisladen ice was originally incorporated at the base of the ice sheet by a simple freeze-on mechanism. If the base of the ice sheet remained near its pressure-melting point, it would then be possible for the soluble gas to diffuse (Weiss and others, I972; Berner and others, 1977) downward along a three-dimensional vein network such as that predicted by Nye and Frank (1973) and observed by Raymond and Harrison (1975). In this manner, air might be introduced to the debris-laden ice. A gas-concentration profile which might result from such a process is shown in Figure 5. The assumptions made in the calculation of this profile were that $16 \mathrm{~m}$ of debris-laden ice were originally air-free, the overlying ice had an air content of I I $\mathrm{ml} / \mathrm{kg}$ ice, the diffusion continued through the ice/sub-ice interface, the diffusion constant was $\mathrm{IO}^{-5} \mathrm{~cm}^{2} / \mathrm{s}$, and the time was Io ooo years. In each case the assumptions made were those least favorable to the diffusion model, and changing any of them would reduce the time necessary to reach the measured gas levels in the basal ice.

If gaseous diffusion has occurred, then it should be reflected in the gas composition. The gas-composition data presented in Table II (personal communication from H. Oeschger) appear to be somewhat complicated by the oxidation of methane in samples containing debris. Samples B and C, which contain debris, both contain a trace of methane, and both display low $\mathrm{O}_{2}$ levels and high $\mathrm{CO}_{2}$ levels with respect to atmospheric air. Original gas compositions were calculated assuming that the original $\mathrm{CO}_{2}$ content was its present-day value of $0.03 \%$ and that the excess $\mathrm{CO}_{2}$ was produced either by a simple oxidation of methane:

$$
\mathrm{CH}_{4}+2 \mathrm{O}_{2} \leftrightarrows \mathrm{CO}_{2}+2 \mathrm{H}_{2} \mathrm{O}
$$

or by the oxidation scheme described by Robbins and others (1973):

$$
0.9 \mathrm{CH}_{4}+\mathrm{r} .7 \mathrm{O}_{2} \leftrightarrows 0.2 \mathrm{CO}+0.7 \mathrm{CO}_{2}+1.8 \mathrm{H}_{2} \mathrm{O}
$$

(Table II). Identical calculations were performed assuming an original $\mathrm{CO}_{2}$ content of $0.2 \%$. In all cases, the calculations produced a composition similar to atmospheric.

Regardless of these complications in the gas composition, the most soluble gas component, Ar, does exhibit behavior which is compatible with gaseous diffusion. There is a relationship between per cent $\mathrm{Ar}$ and total gas content such that $\mathrm{Ar}$ is most enriched in samples with the least amount of air. The enrichment of Ar in the debris-laden zone ought to be coupled with a depletion of Ar in the upper zone where diffusion originated. This is the combined effect of the relatively high solubility of $\mathrm{Ar}$ in water and the relatively fast diffusion of $\mathrm{Ar}$ with respect to $\mathrm{N}_{2}$. The process of selective gaseous transport envisioned here is similar to the selective gaseous removal model for temperate glaciers proposed by Berner and others ( 1977 ). 
TABH.1 11. GAS COMPOSTION*

\begin{tabular}{|c|c|c|c|c|c|c|c|c|}
\hline Sample ${ }^{\dagger}$ & $\begin{array}{c}\text { Total gas } \\
\text { mal kg }\end{array}$ & $\begin{array}{l}\mathrm{N}_{2} \\
{ }_{\mu}\end{array}$ & $\begin{array}{l}\mathrm{O}_{2} \\
\mathrm{O}_{1 .}\end{array}$ & $\begin{array}{l}\Delta r \\
y_{0}\end{array}$ & $\begin{array}{l}\mathrm{CO}_{2} \\
\%_{0}\end{array}$ & $\begin{array}{r}\operatorname{Ar} \mathrm{X}_{2} \\
=100\end{array}$ & $\begin{array}{c}\mathrm{O}_{2} / \mathrm{N}_{2} \\
=10\end{array}$ & $\begin{array}{r}\mathrm{Ar}()_{2} \\
\quad 100\end{array}$ \\
\hline \multicolumn{9}{|c|}{ Measured composition } \\
\hline$A$ & $6+9$ & -8.11 & 20.75 & 0.94 & 0.20 & 1.20 & 2.66 & 4.53 \\
\hline B & $4^{6.7}$ & 79.11 & 18.74 & 1.08 & 1.07 & 1.37 & 2.37 & $5 \cdot 7^{6}$ \\
\hline C: & 56.3 & 79.83 & 17.86 & 1.00 & 1.31 & 1.25 & 2.24 & 5.60 \\
\hline D) & 59.4 & $78.5^{6}$ & 20.14 & 1.00 & 0.30 & 1.27 & $2.5^{6}$ & 4.97 \\
\hline Average & & 78.90 & $19 \cdot 37$ & $1.0 \mathrm{I}$ & 0.72 & 1.27 & $2.4^{6}$ & $5 \cdot 22$ \\
\hline \multicolumn{9}{|c|}{ Original composition } \\
\hline \multicolumn{9}{|c|}{ Assume $\mathrm{COO}_{2}=0.03{ }^{\prime \prime}$ " and $\mathrm{CH}_{4}+{ }_{2} \mathrm{O}_{2} \leftrightarrows 2 \mathrm{H}_{2} \mathrm{O}$} \\
\hline$A$ & 65.0 & $77.9^{8}$ & 21.05 & 0.94 & 0.03 & 1.20 & 2.70 & $4 \cdot 4^{6}$ \\
\hline B & 47.2 & 78.30 & 20.61 & I.07 & 0.03 & 1.37 & 2.63 & 5.19 \\
\hline C : & 57.0 & 78.82 & 20.16 & 0.99 & 0.03 & 1.25 & 2.56 & 4.90 \\
\hline D & 59.6 & 78.35 & 20.62 & 1.00 & 0.03 & 1.27 & 2.63 & 4.84 \\
\hline \multirow[t]{2}{*}{ Average } & & 78.36 & 20.61 & 1.00 & 0.03 & 1.27 & 2.63 & 4.84 \\
\hline & \multicolumn{8}{|c|}{ Assume $\mathrm{CO}_{2}=0.03^{\circ}{ }^{\circ}$ and $0.9 \mathrm{CH}_{4}+1.7 \mathrm{O}_{2} \leftrightarrows 0.2 \mathrm{CO}+0.7 \mathrm{CO}_{2}+1.8 \mathrm{H}_{2} \mathrm{O}$} \\
\hline$A$ & 65.1 & 77.92 & 21.11 & 0.94 & 0.03 & 1.20 & 2.71 & $4 \cdot 44$ \\
\hline B & $47 \cdot 4$ & 77.95 & 20.95 & 1.06 & 0.03 & 1.37 & 2.69 & 5.08 \\
\hline C: & $57 \cdot 3$ & 78.40 & 20.59 & $0.9^{8}$ & 0.03 & 1.25 & 2.63 & 4.77 \\
\hline D & 59.6 & 78.26 & 20.72 & 1.00 & 0.03 & 1.27 & 2.65 & $4.8 \mathrm{I}$ \\
\hline Average & & 78.13 & 20.84 & 1.00 & 0.03 & 1.27 & 2.67 & 4.77 \\
\hline Atmosphe & $\mathrm{ir}_{+}^{+}$ & 78.08 & 20.95 & 0.93 & 0.03 & 1.20 & 2.68 & $4 \cdot 4^{6}$ \\
\hline
\end{tabular}

* Gas-composition measurements performed at University of Bern (personal communication from $\mathrm{H}$. Oeschger).

+ Sample A taken from above debris-laden zone at depth of $1356.26 \mathrm{~m}$.

Sample B taken from ice containing debris at depth of $1361.67 \mathrm{~m}$.

Sample (: taken from ice containing debris at depth of $1363.86 \mathrm{~m}$.

Sample D taken from clear ice within debris-laden zone at depth of $1363.91 \mathrm{~m}$.

$\ddagger$ CRC handbook of chemistry and physics. Fiftr-fourth edition (Weast, 1973).

\section{SuMmARY AND CONCLUSIONS}

The debris-laden zone in the Camp Century basal ice represents the first observed contact with debris-laden ice from the interior of a continental ice sheet. The presence of debris within the lowest $15.7 \mathrm{~m}$ of ice suggests that debris incorporation is not confined to ice marginal areas. An investigation of the structure and composition of the ice and its solid and gaseous inclusions provides valuable information concerning the origin and deformational history of the basal ice.

On the basis of the debris analysis, it is concluded that the source of the debris is the frozen till at the base of the ice sheet rather than surficial deposits. This conclusion is based on (a) large particle sizes relative to atmospherically transported dust, (b) high debris concentrations relative to atmospherically transported debris, and (c) textural features indicating glacial abrasion. In addition, the mineralogical composition of the debris is compatible with a tilllike origin, and the color of the debris-laden ice is similar to the color of the underlying till material.

The gas analysis provides evidence which supports the freezing-on mechanism for the origin of the Camp Century basal ice. Although the gas composition has been somewhat modified, the argon content and the gas concentration in the debris-laden zone indicate that gaseous diffusion has occurred. The diffusion model accounts for the presence of gas inclusions in the ice, the lack of bubble stratification, and the lack of spatial relationship between bubbles and solid particles without discrediting the freeze-on model. The selective mechanism of freezing can account for the small particle sizes in the debris-laden zone. While other 
mechanisms, in particular regelation, may play a role in the incorporation of debris at the base of the Camp Century core, it appears that freeze-on is the dominant process. The ice texture and fabrics in the Camp Century basal ice provide valuable information concerning recent conditions at the base of the ice sheet. The extremely fine-grained highly oriented ice crystals in the lowest $10 \mathrm{~m}$ imply that it is a zone of high deformation.

\section{Acknowledgements}

This research was sponsored by the National Science Foundation's Department of Polar Programs. The work was performed at the State University of New York at Buffalo as part of the Polar Ice Core Analysis Program (PICAP) of the Ice Core Laboratory, Department of Geological Sciences, and was submitted (by S.L.H.) in partial fulfillment of the requirements for the degree of Master of Arts.

\section{REFERENCES}

Anderton, P. W. 1974. Ice fabrics and petrography, Meserve Glacier, Antarctica. Fournal of Glaciolog), Vol. 13,
No. 68, p. 285 . 306 . Bari, S. A., and Hallett, J. 1974. Nucleation and growth of bubbles at an ice water interface. Journal of Glaciolog);
Vol. 13 , No. 69, p. 489520 .

Benson, C. S. 1959. Physical investigations on the snow and firn of northwest Greenland 1952, 1953, and 1954. U.S. Snow, Ice and Permafrost Research Establishment. Research Report 26.

Berner, W., and others. 1977. Analysis and interpretation of gas content and composition in natural ice, [by| $W$. Berner, P. Bucher, H. Oeschger, and B. Stauffer. [Lnion Géodésique et Géophysique Internationale. Association Internationale des Sciences Hydrologiques. Commission des. Veiges et Glaces. I Simposium. Isolopes et impuretés dans les neiges et glaces. Actes du colloque de Grenoble, août/septembre 197.5, p. 272-84. (IAHS NISH Publication No. 118. Bishop, B. C. 1957. Shear moraines in the Thule area, northwest Grecnland. U.S. Snow. Ice and Permafrost
Research Establishment. Research Report 17 .

Boulton, G. S. 1967 . The development of a complex supraglacial moraine at the margin of Sorbreen, Ny Friesland, Vestspitsbergen. Journal of Glaciology, Vol. 6, No. 47, p. 717-35.

Boulton, G. S. 1970. On the origin and transport of englacial debris in Svalbard glaciers. Fournal of Glaciolog),
Vol. 9 , No. 56, p. 21329 .

Boulton, G. S. 56, p. $213-29$.

comp. Polar geomorpholog). London thermal régime in glacial sedimentation. (In Price, R. J., and Sugden, D. E., Special Publication No. London, Institute of British Geographers, p. 1-19. (Institute of British Geographers.

Boulton, G. S. ["I975.] Processes and patterns of subglacial sedimentation: a theoretical approach. (In Wright, A. E., and Moseley, F., ed. Ice ages: ancient and modern. Liverpool, Seel House Press, p. 7 42. (Geological Journal
Special Issue No. 6.))

Coachman, L. K., and others. 1958. Gases in glaciers, [by] L. K. Coachman, E. Hemmingsen, P. F. Scholander, T. Enns, and H. De Vries. Science, Vol. 127, No. 3309, p. 1288-89. Corte, A. E. 1962 . Vertical migration of particles in front of a moving freezing plane. Journal of Geophysical
Research, Vol. 67, No. 3, p. 1085-90.

Cragin, J. H., and others. 1977 . Interhemispheric comparison of changes in the composition of atmospheric precipitation during the late Cenozoic era, [by] J. H. Cragin, M. M. Herron, C. C. Langway, Jr, and G. [A.] Klouda. (In Dunbar, Maxwell J., ed. Polar oceans. Proceedings of the Polar Oceans Conference held at McGill University, Montreal, May, 1974. Sponsored by the Scientific Committee on Oceanic Research (SCOR) and by the Scientific Committee on Antarctic Research (SCAR), of the International Council of Scientific Unions. Calgary, Alberta, Arctic Institute of North America, p. $617-31$. Crozaz, G., and Langway, C. C., jr. 1966 . Dating Greenland firn-ice cores with Pb-21o. Earth and Planetary
Science Letters, Vol. 1, No. 4, p. 194 96 . Dansgaard. W.. and Johnsen, S. J. 1969. A flow model and a time scale for the ice core from Camp Century,
(ircenland. Fournal of (ilaciolog), lol. 8. No. 53. p. $215-23$.

Dansgaard, 1 ., and others. 1969. One thousand centuries of climatic record from Camp Century on the Greenland ice sheet, [by] W. Dansgaard, S. J. Johnsen, J. Moller, C. C. Langway, Jr. Science, Vol. 166, No. 3903 ,
p. 377 . 8 . Goldthwait, R. P. 1951. Development of end-moraines in east-central Baffin Island. Fournal of Geology, Vol. 59,
No. 6. p. 56777 . Goldthwait, R. P. 1960 . Study of ice cliff in Nunatarssuaq, Greenland. U.S. Snow, Ice and Permafrost Research
Establishment. Technical Report 39 .

Gow, A. J. 1970. Preliminary results of studies of ice cores from the $2164 \mathrm{~m}$ deep drill hole, Byrd Station, Antarctica. [Linion Gésdesique et Géophrsique Internationale. Association Internationale d'Hydrologie Scientifique.] Scientific Hydrology. Commission of Snow and Ice.] International Symposium Research. International Association of (IS.ACE), Hanover Vere Hampshire Snow and Ice.] International Symposium on Antarctic Glaciological Exploration Internationale d'Hydrologie Scientifique] 3 . September 19/68, p. 78 -9o. [(Publication No. 86 [de l'Association 
Gow, A. J. 1971. Relaxation of ice in deep drill cores from Antarctica. Journal of Geophysical Research, Vol. 76, No. 1 I , p. $2533-4$ I

Gow, A. J., and Williamson, T. 1975. Gas inclusions in the Antarctic ice sheet and their significance. U.S. Cold Regions Research and Engineering Laboratory. Research Report 339.

Hansen, B. L., and Langway, C. C., jr. 1966. Deep core drilling in ice and core analysis at Camp Century, Greenland, 196-1966. Antarctic Fournal of the United States, Vol. I, No. 5, p. 207-08.

Herron, S. L., formerly Hoar, S. L., and Langway, C. C., jr. 1978. Total gas content in the deep ice core from Camp Century, Greenland. Geological Society of America. Abstracts with Programs, Vol. 10, No. 2, p. 47.

Holdsworth, G. 1974. Meserve Glacier, Wright Valley, Antarctica: part 1. Basal processes. Ohio State University. Institute of Polar Studies. Report No. 37.

Kamb, W. B. 1973. Experimental recrystallization of ice under stress. (In Heard, H. C., and others, ed. Flow and fracture of rocks, edited by H. C. Heard, I. Y. Borg, N. L. Carter, and C. B. Raleigh. Washington, D.C., American Geophysical Union, p. 2 I I-4i. (Geophysical Monograph 16.))

Kamb, W. B., and LaChapelle, E. R. 1964. Direct observations of the mechanism of glacier sliding over bedrock. Journal of Glaciology, Vol. 5, No. 38, p. I 59-72.

Kumai, M. 1977. Electron microscope analysis of aerosols in snow and deep ice cores from Greenland. [Union Géodésique et Géophysique Internationale. Association Internationale des Sciences Hydrologiques. Commission des Neiges et Glaces.] Symposium. Isotopes et impuretés dans les neiges et glaces. Actes du colloque de Grenoble, août/septembre 1975, p. $34 \mathrm{I}-50$. (IAHS-AISH Publication No. 118. )

Langway, C. C., jr. 1958[a]. Bubble pressures in Greenland glacier ice. Union Géodésique et Géophysique Internationale. Association Internationale d'Hydrologie Scientifique. Symposium de Chamonix, I6-24 sept. 1958, p. 336-49. (Publication No. 47 de l'Association Internationale d'Hydrologie Scientifique.)

angway, C. C., jr. I958[b]. Ice fabrics and the universal stage. U.S. Snow, Ice and Permafrost Research Establishment. Technical Report 62.

Lorius, C. 1967. A physical and chemical study of the coastal ice sampled from a core drilling in Antarctica. Union de Géodésie et Géophysique Internationale. Association Internationale d'Hydrologie Scientifique. Assemblée générale de Berne, 25 sept. -7 oct. 1967. [Commission de Neiges et Glaces.] Rapports et discussions, p. 141-48. (Publication No. 79 de l'Association Internationale d'Hydrologie Scientifique.)

Mock, S. J. I965. Glaciological studies in the vicinity of Camp Century, Greenland. U.S. Cold Regions Research and Engineering Laboratory. Research Report 157.

Murozumi, M., and others. 1969 . Chemical concentrations of pollutant lead aerosols, terrestrial dust, and sea salts in Greenland and Antarctica snow strata, [by] M. Murozumi, T. J. Chow, and C. Patterson. Geochimica et Cosmochimica Acta, Vol. 33, No. 10, p. 1247-94.

Nakaya, U. 1956. Properties of single crystals of ice, revealed by internal melting. U.S. Snow, Ice and Permafrost Research Establishment. Research Paper 13.

, J. F. and Frank, F. C. 1973. Hydrology of the intergranular veins in a temperate glacier. Union Géodésique et Géophysique Internationale. Association Internationale d'Hydrologie Scientifique. Commission de Neiges et Glaces. Symposium on the Hydrology of Glaciers, Cambridge, 7-13 September 1969, p. 157-61. (Publication No. 95 de 1'Association Internationale d'Hydrologie Scientifique.)

Raymond, C. F and Harrison, W. D. 1975. Some observations on the behavior of the liquid and gas phases in temperate glacier ice. Fournal of Glaciology, Vol. 14, No. 71, p. 213-33.

Raynaud, D., and Lorius, C. 1973. Climatic implications of total gas content in ice at Camp Century. Nature, Vol. 243 , No. 5405 , p. $283-84$.

Rigsby, G. P. 1960. Crystal orientation in glacier and in experimentally deformed ice. Fournal of Glaciology, Vol. 3 , No. 27 , p. 589-6o6.

Robbins, R. C., and others. 1973. Analysis of ancient atmospheres, [by] R. C. Robbins, L. A. Cavanagh, and L. J. Salas, E. Robinson. Journal of Geophysical Research, Vol. 78, No. 24, p. 5341-44.

Shumskiy, P. A. 1958. The mechanism of ice straining and its recrystallization. Union Géodésique et Géophysique

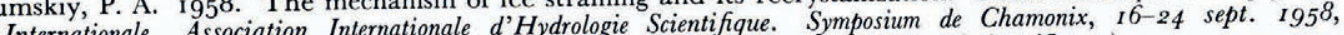
Internationale. Assiciation No. 47 de l'Association Internationale d'Hydrologie Scientifique.)

Souchez, R. A. 1967 . The formation of shear moraines: an example from south Victoria Land, Antarctica. Fournal of Glaciology, Vol. 6, No. 48, p. 837-43.

Steinemann S. Union Géodésique et Géophysique Internationale. Association Internationale d'Hydrologie Scientifique. Symposium de Chamonix. $16-24$ sept. 1958 , p. 254-65. (Publication No. 47 de l'Association Internationale d'Hydrologie Scientifique.)

Swinzow, G. K. 1964. Investigation of shear zones in the ice cap margin Thule, Greenland. U.S. Cold Regions Research and Engineering Laboratory. Research Report 93.

Weast, R. C., ed. 1973. CRC handbook of chemistry and physics. Fifty-fourth edition. Cleveland, Ohio, Chemical Rubber Publishing Co.

Weertman, J. 196I. Mechanism for the formation of inner moraines found near the edge of cold ice caps and ice sheets. Fournal of Glaciology, Vol. 3, No. 30, p. 965-78.

Weertman, J. Cold Regions Research and Engineering Laboratory. Research Report 162.

Weertman, J. I 966 . Effect of a basal water layer on the dimensions of ice sheets. Fournal of Glaciology, Vol. 6 , No. 44 , p. $191-205$

Weertman, J. 1968. Diffusion law for the dispersion of hard particles in an ice matrix that undergoes simple shear deformation. Fournal of Glaciology, Vol. 7 , No. 50, p. $161-65$.

Weertman, J. 1972. General theory of water flow at the base of a glacier or ice sheet. Reviews of Geophysics and Space Physics, Vol. 10, No. 1, p. 287-333.

Weertman, J. 1976. Sliding-no-sliding zone effect and age determination of ice cores. Quaternary Research, Vol. 6, No. 2, p. 203-07. 
Weiss, R. F., and others. 1972. Compositional variations of gases in temperate glaciers, [by] R. F. Weiss, P. Bucher, H. Oeschger, and H. Craig. Earth and Planetary Science Letters, Vol. 16, No. 2, p. I78-84.

Whalley, W. B., and Langway, C. C., jr. In press. A scanning electron microscope examination of subglacial quartz grains from Camp Century, Greenland-a preliminary study. Fournal of Glaciology.

Woo, C. C., and others. 1976. Scanning-electron-microscope examination of sand-grain particles from an ice core from Camp Century, northwest Greenland, [by] C. C. Woo, R. F. Commeau, C. C. Langway, Jr. Geological Society of America. Abstracts with Programs, Vol. 8, No. 6, p. I I 76.

\section{DISCUSSION}

L. A. Lliboutry: Did you make any comparison with the shear moraines of the TUTO ramp?

S. L. Herron: We have not examined material from the shear moraines; however, there are vast differences between these and the Camp Century debris-laden ice. For example, the shear moraines have bands of bubble-free ice and zones with large particles and boulders, none of which are present in the Camp Century core.

T. J. Hughes: There is a controversy among glacial geologists as to whether the Greenland ice sheet was larger and merged with Ellesmere Island ice 20000 years ago. If not, then your postulated basal-melting event occurred in a present basal melting zone somewhere between Camp Century and the Greenland ice divide. But, if merger occurred, your basal-melting event may have occurred in a former basal-melting zone that was much closer to Camp Century, with ice moving from a more north-eastern ice divide. Is there anything in your analysis, in conjunction with other work, that would allow you to distinguish between these two possibilities? In particular, simple-shear creep tests on your ice cores at the pressuremelting point and at the present basal temperature should tell you the maximum distance from Camp Century at which the basal-freezing event could have taken place 20 ooo years ago. Was it $10 \mathrm{~km}, 100 \mathrm{~km}$, or what?

Herron: Our present model requires about io ooo years of diffusion to introduce air into the debris-laden zone. Aside from this, it is impossible to tell when and where basal melting occurred.

D. A. Fisher: Do you know what sized particles are mainly responsible for your discoloured layers, i.e. have you any size distribution?

Herron: It appears that the clay-size particles are largely responsible; however, a systematic study of colour versus particle size has not been done. 